\title{
The Aesthetic Experiment of Oscar Wilde in $A$ House of Pomegranates
}

\author{
Jing Hou \\ Huaiyin Institute of Technology, Huai'an, China
}

\begin{abstract}
Oscar Wilde (1854-1900) is one of major proponents of Aestheticism in England. This thesis attempts to probe into Oscar Wilde's second collection of fairy tales-A House of Pomegranates, which is complicated and abstruse in aspects of language, theme and narration, compared with his first collection of fairy tales-The Happy Prince and Other Tales. The author contends that A House of Pomegranates, which is subversive of the fairy tale convention, is brought forward by Wilde's aesthetic intentions - art is independent of life and immortal, thus, an experiment in aestheticism. The approach of textual analysis and comparison are adopted in this thesis.
\end{abstract}

Index Terms - Oscar Wilde, A House of Pomegranates, aestheticism, experiment

\section{INTRODUCTION}

Oscar Wilde (1856-1900), Irish poet, dramatist, novelist and essayist, is one of the two most important exponents of Aestheticism in English literature. From the eighties to the nineties in the 19th century, Wilde wrote and published all his major works, including his famous plays_-four comedies and one tragedy, his sole novel-The Picture of Dorian Gray, a series of critical essays collected in Intentions, two collections of fairy tales-The Happy Prince and Other Tales and A house of Pomegranates. His works, full of epigrams and paradoxes, reveal the ugliness of the bourgeois society and his unique aesthetic philosophy as well.

A House of Pomegranates, with four short stories symbolizing four seeds eaten by Persephone-the queen of the underworld, is the second collection of fairy tales of Oscar Wilde. The four stories are "The Young King", "The Birthday of the Infanta", "The Fishman and His Soul" and "The Star child". It was considered unfit for children because of its complex plot and deep insight into life and society when first published. The current thesis intends to unearth the aesthetic ideas embedded in A House of Pomegranates, giving full play to close reading of the text. This thesis examines every pomegranate in detail, seeking the signs and symbols of aestheticism left by Wilde while conceiving to confirm the experiment carried out by Wilde in the field of fairy tale.

\section{THe MAJOR Aesthetic CONCEPTIONS OF OSCAR Wilde}

No name is more evidently bound up with the aesthetic movement of the 1880s and 1890s in England than that of Oscar Wilde. This connection results as much from the sensational details of Wilde's life as from his aesthetic theories collected in his critical works or scattered in his works. Wilde breaks out of the yore of the tradition and transcends his predecessors by putting forward a series of unprecedented ideas on art and creation. Although Wilde's philosophy is far from systematic and even illogical, it is coherent in the sense that the same spirit of aestheticism consistently links it. Tangled as Wilde aesthetic principles are, it is, nevertheless, likely for us to clear out several general principles.

Firstly, for Wilde, art transcends morality. He claims in his critical book Intensions that all art is immoral, "except those baser forms of sensual or didactic art that seek to excite to action of evil or of good" 1 . By "immoral", Wilde means that art is useless, expressing neither love for nor hate against good or evil. However, it does not indicate that Wilde is free from moral concerns, for Wilde is equally concerned with the same problems confronting his contemporaries and such intellectual giants as Ruskin, Carlyle and Arnold. Nevertheless, on the perplex relationship between the good and the evil, he thinks otherwise. He maintains that art and ethics belong to separate categories.

Secondly, Wilde maintains that art is independent of life, and it holds the mirror up for life. The negation of life's effects on art forms only the first phase of Wilde's assertions on the relationship between life and art, which is elaborately dealt with in Wilde's critical essay "The Decay of Lying". Wilde expresses his protest against nature, which symbolizes the vulgar real-life for him. As a result, art is not to be found in nature herself. He is convinced that "Nature is always behind the age", and he proceeds to say, "And as for life, she is the solvent that breaks up Art, the enemy that lags waste her house" 2 .

Thirdly, Wilde puts great emphasis on form and the innovation of form. Wilde gives great priority to form, and energetically advocates reform and innovation, which are, to some extent, overlapping with the autonomy of art. He proposes, for the sake of absolute autonomy of art, the artist should be an individualist, who has the final say to

\footnotetext{
${ }^{1}$ Wilde, Oscar. Intentions2. Kingbook International Digital Library. 10 Nov. $2008<$ http://202.119.108.52:8077/Soft_Show.asp?SoftID=5744>

2 Wilde, Oscar. Intentions1. Kingbook International Digital Library. 10 Nov. $2008<$ http://202.119.108.52:8077/Soft_Show.asp?SoftID=5743>
} 
everything concerning his own work. Wilde considers that only through reform and innovation can the artist attain self-development and achieve the complete independence of art.

\section{Aestheticism in A House of POMEGRANATES}

The most obvious sign of Wilde's expression of aesthetic ideas in A House of Pomegranates is the detailed description of Beauty. As is known to all, traditional fairy tales are very vague in describing the beautiful appearance of human beings and costumes, but Wilde insists on the converse. In A House of Pomegranates, Wilde's lingering on concrete beauty is immensely prominent. In "The Birthday of the Infanta", for example, Wilde dwells on the grace of those slim Spanish children: how elegantly they are dressed and how graceful their manners are. More importantly, the description of the beautiful costume of the princess is considerably elaborate. Her robe was and skirt was decorated with silver, fine pearls and gold (Wilde, 1968).

In addition, when the dwarf is looking for the princess, Wilde delays him by the magnificence of the sumptuous decoration in the palace, turning the beauty of these rooms into tangible words. The walls alone is quite impressive, covered with a pink-flowered Lucca damask with birds patterns and silver blossoms, and the furniture is made of silver designed with florid wreaths (Wilde, 1968). Wilde creates all these beautiful concrete images that fascinate the dwarf.

It is the same in "The Fisherman and His Soul". When describing the little mermaid, although Wilde casts away the abstract word "beautiful", he brings forward quite an amazing picture with vivid marvelous word painting. The fisherman falls in love with her for good reasons that the readers are aware of. What's more, when the fisherman is allured by the young witch to go to the top of the mountain to dance, there appears a man under the shadow of a rock. The fashion of his costume is also described in great detail, despite the fact that it is not really conducive to the development of the plot.

In "The Star-child", the star-child's curls that resemble the rings of the daffodil, his ivory skin, and his beautiful lips, eyes, and body together present a fancy picture. Besides, the wonderland discovered by the young king, and those rare and costly material that holds a great fascination for him is also in vivid description.

In these tales, Wilde's unconventional artistic treatment of beauty confirms one of his major aesthetic theories-art is immoral. Wilde is conveying his aversion to utilitarianism in A House of Pomegranates through the concrete and detailed description of beauty, which is independent of social mores. In these stories, beauty loses its social function as the carrier of virtues; instead, it becomes an end itself, while fairy tales before Wilde tend to associate beauty with morals. Traditionally, the heroines, more often than not, are not only beautiful and but also kind, while their antagonists ugly and evil. Wilde changes this mode and dissociates beauty from morals. For instance, in "The Birthday of the Infanta", the princess is beautiful, the most graceful of all children, but she is cruel and indifferent to the sudden death of the little dwarf who renders her much happiness earlier during daytime. Another case in point is the star-child, who is rather fair, but his beauty work does him no good, because he is proud, and cruel, and selfish when he grows up. The child despises other children of the same village and regards himself the master. He has no pity for the poor, or for those who are afflicted in some way. He even sends his mother away, who has been looking for him for years. It is not until he turns ugly does he begin to repent of his sin. Moreover, in "The Yong King", the rare and beautiful objects are closely related to tears, blood or even death. For example, those beautiful pearls are obtained at the price of slaves' lives. In addition, the mermaid, who is of rare beauty, has no soul at all.

The minute depiction of the scene in the garden of the palace, the charming performance arranged for the princess in "The Birthday of the Infanta" and the detailed description of the costume of the strange person worshipped by all the witches in "The Fisherman and the Soul" are all brimmed with beauty, yet they are not connected to the evolvement of the plot. Consequently, Wilde's infatuation with beauty functions not as a vehicle for moral teachings, but is the supreme end of art. The lingering sculpture of beauty, which seems unnecessarily redundant, further proves Wilde's aestheticism. All these instances are Wilde's weapons against the function of beauty and art, for he believes that art is useless, caring for neither right or wrong, and the aim of art lies in the perfection of itself. Wilde reiterates that the real artist should have no ethical sympathies at all, because beauty is the only compass for art. To make every detail perfect and pure is what Wilde intends. He holds that intellectual virtues are what the artist and his art need to transcend, because the moral life of man forms but part of the subject matter of the artist, and the sculpture of evils hold the same temptation for him.

The second distinguishing point about A House of Pomegranates is the unexpected endings, which also indicates Wilde's aestheticism. The ending of typical traditional fairy tales, more often than not, can be expected, while in $A$ House of Pomegranates, three stories, out of total four, end with the sudden deaths of the heroes. Wilde's way of concluding a story is in direct contrast with what is anticipated. "The Star-child" is the most dramatic of all the four stories. The star-child turns from an evil child to a good person and contrives to redeem himself, and to retrieve his mother, which are achieved through thick and thin. During his brief reign, he shows much sympathy for the suffered. He bears no cruelness to bird or beast, and teaches kindness and charity to all the people. There is peace and splendor in his land. Until then, happy ending has been expected. However, Wilde arranges the anti-climax - the premature death of the star-child. Yet his reign only lasts for three years and then he dies unexpectedly. His successor is very cruel but rules the county for a long time (Wilde, 1968). The readers cannot but notice that the kindness is not reciprocated and the moral order has not been restored. 
In "The Birthday of the Infanta", the dwarf entertains all the audience. He is kind to the animals, sharing his nuts with the squirrels. He never forgets the birds, and feeds them crumbs although he only has a small helping of food. Kind as he is, he is not able to obtain the love from the beautiful princess, which is quite different from the treatment received by the frog prince in The Princess and the Frog. Instead, when the truth - the little princess whom he loves dearly is merely mocking at his ugliness dawns upon him, he ceases to be out of a broken heart. The princess shows no pity for his death, instead, she gives orders that she would only play with people who has no heart (Wilde, 1968). There is neither regret nor expiation for the sins. Wilde abandons the invariable pattern that the good is rewarded and the ill punished. For him, both the moral and the immoral are rough material for further creation.

Furthermore, in the "The Fisherman and His Soul", the narration continues when the fisherman cuts off his soul and plights himself to the little mermaid when readers least expect it. The fisherman and the mermaid are supposed to be happy ever after. Nevertheless, Wilde brings forward the question of body, soul and heart. The soul travels and experiences, while the body and love remain in the sea. The romance is broken when the soul returns for the third time and entices the fisherman with the feet of a dancing girl. The fisherman leaves his beloved mermaid. Finally, realizing that the sins of the soul, the fisherman is resolved to return, but it is impossible to get rid of his soul the second time. The soul makes every effort to get into the body, but with no success. When the soul is on the verge of giving up, the fisherman gives in out of pity. At this news, the mermaid dies (Wilde, 1968). Only then is the value of love brought to light without reserve: love surpasses wisdom and riches in value. The sudden death befalls the couple, and the black color of it reverses the happy aura around traditional fairy tales. The story does not end here as is conjectured. Three years later, beautiful flowers with aroma are discovered in the corner of the Field of the Fullers where the couple are buried. These flowers make the priest speak of the God whose name is love (Wilde, 1968). The irony is that after people pray for the world in the sea, the flowers never appear again.

All these odd endings provide further support for Wilde's aesthetic views. They differ from traditional fairy tales in the fulfillment the moral function. On the one hand, these odd endings prove Wilde's insistence on the immorality of art: art is not a means to inform the public of right and wrong. Wilde's opposition against utilitarianism is made clear as well. On the other hand, these unexpected endings demonstrate Wilde's willingness and advocacy of creation and transcendence. He intends to break the old order and establish the new, as Shillinglaw (2006) points out that Wilde's aesthetic motive subverts the notion of moral. The sudden deaths are out of the expectation of the readers, but they echo to the creational spirit of Oscar Wilde. Wilde is a rebel against the tradition, advocating the spirit of creation in art. Wilde seeks to transform the fairy tale discourse - to change both in content and style, which is fully embodied in the sudden conclusion of fairy tales with abrupt deaths. The melancholy tone replaces the tone of happiness: whatever the effort, the end is doomed. It is apparent that Wilde is determined to subvert the messages conveyed by the modes set by classical fairy tales.

The third eye-catching characteristic of A House of Pomegranates is the detailed suffering. One case in point is the star-child. The Star-child turns ugly after turning his mother away. For three years, he has been in exile seeking his mother. How he suffers is not dealt with a few words, but dwelled upon. He wanders over the world where he is treated brutally, where he can not find love. He is treated exactly the way he treats others earlier when he is beautiful. The village children mocked him, and threw stones at him, and the carlots forbid him to sleep in the byres. At one time, he is a beggar, tired and feet bleeding; at another time, he is sold as a slave and cast into a dungeon. He is sent to search for the white, yellow, and red gold successively. Moreover, his life is threatened all the time and his way to expiation is uneven.

The same minute depiction appears again in the case of the bereavement of the king in "The Birthday of the Infanta". The melancholy of the king would have been flitted through with a few words; however, Wilde dwells on the details of the love and sorrow of the king for the dead queen. He is in constant mourning for the queen who died twelve years ago. He loves her so much that he embalms her body and keeps her in a chapel where he visits every month (Wilde, 1968). He carries his sorrow to such an extent that he carries on his mourning despite the opposition and thus loses his land, which is seemingly irrelevant to the major plot.

The striking imagery of violent cruelty is nightmare for children, and is rare in traditional fairy tales which are supposed to be created for children. It is evident that Wilde is obsessed with the description of pain and suffering in $A$ House of Pomegranates, where there are unreciprocated love and unprovoked death in every story. Ruggaber (2003) holds that Oscar Wilde challenges aesthetic principles in A House of Pomegranates.

Under the cover of the fairy tale genre, he exposes the same issue of moral, only deeper, as he once marked that people will tell the truth if given a mask. Wilde declares finds the masks that people wear about in a good society much more interesting than what is behind the masks. Wilde contends that art should contain anything actually happened, or happens frequently in real life, so the truth is disclosed through imaginary stories and characters. The unusual revelation of cruelty and suffering challenges his readers to reflect on several social and moral problems, such as the questioning of institutions, the value of beauty and moral complexity.

However, the handling of the plots in A House of Pomegranates does not offer traditional morals in a conventional way. For example, the tragic scene of the death of the dwarf fails to arouse the conscience in the beautiful princess. She is as cruel as ever, for she gives the order that those who come to play with her should possess no hearts in the future. This story does not attempt to provide ready morals, while it does drive the readers to analyze on their own. It is the 
society, which values beauty more than anything does, that renders the princess indifferent to the extreme suffering. Moreover, the plot of conspiracy against the queen is neglected. Neither is the criminal punished nor is the justice restored. As for the star-child, the more intense is his suffering, the more convincing is the aesthetic values of Wilde explicit in this story, as he considers that the question of right or wrong is more complex than assumed.

In stating that art is immoral, Wilde is against the hypocrisy of the society, against those who preach right and wrong; because there is indeed injustice in the world and the evil is not necessarily punished. Wilde assumes that it is an unpardonable mannerism to implant morality in the works of art. Under the mask of fairy tale the genre, Wilde introduces the reality of life to children: life has suffering as its inevitable part. Bruno Bettelheim's influential study in child psychology, The Uses of Enchantment, suggests that fairy stories impart us much about the inner problems of human beings and they also describe human mind, which is certainly true of Wilde's tales. Invariably, Wilde reveals the dark side of life: the humanity is not human. The fairy tale genre serves as the cover for Wilde's serious writing.

Besides the three points mentioned above, the digression in A House of Pomegranates also contributes to Wilde's aestheticism. The mystery of it lies in the unusually detailed secondary information, which leads to digression from the major plot. Wilde wanders away from the primary plot many a time. For instance, in "The Birthday of the Infanta", the love story of the king and the belated queen runs on into more than two pages: how they meet and are betrothed, how he loses her and mourns for her, which should have been merely mentioned. Besides, in "The Birthday of the Infanta", before the show of the little dwarf, Wilde pours out many words to depict the precedent five performances with one paragraph dedicated to each of them. With these unnecessary details, the performance of the dwarf is not given proper prominence. Wilde introduces the dwarf's performance with just a few words: the funniest part (Wilde, 1968). Here the emphasis on the dwarf is not quite persuasive as it likely to be in traditional tales, since the length of the show is not distinguished.

In "The Star-Child", the hero are supposed to be the star-child, however, it is not until the fourth page does the child appear. The background information with regard to the baby's parentage would have been put in a few words as a deserted baby found in the winter pine-forest. However, Wilde describes it in great detail. At first, a dramatic discussion among animals about the cold weather is on display, followed by the struggle in the icy forest of the two woodcutters, which may be engaging, but superfluous, compared with traditional fairy tales.

The most puzzling digression arises in "The Fisherman and His Soul". The young fisherman goes to the witch to seek help. The witch promises to help him send his soul away only on the condition that he dances with her. Magic and witches recur in traditional fairy tales, but the magic here is associated with mystery. The dance, the bizarre scene of dancing with the witches, the strange man leaves the reader encompassed with doubts.

As we all know, Wilde is highly talented and well-read in classics, so he must be versed in fairy tales. Therefore, the only justification for the digression in A House of Pomegranates is his intention to exercise his aesthetic philosophy, to make every detail perfect and beautiful. He claims that the social ideas and the meaning of joy in art consist in "the flawless beauty and perfect form of its expression"3. For the sake of beauty, which Wilde holds as his God, he makes it rule to render the details perfect.

In addition, the digression that brings vigor and suspense into the old story pattern breaks the convention, conforming to Wilde's tendency to break the old and to establish the new. To Wilde, form is the highest principle, and the creation in form is still more important. He clarifies himself that "The simple utterance of joy is not poetry any more than a mere personal cry of pain." Emotions are subordinate to the governing artistic form, without which, the feelings make no sense. "The absolute distinction of the artist is not his capacity to feel nature so much as his power of rendering it." Language goes before thought for Wilde; therefore, it's important to create within the fairy tale genre. The digression that does not comply with the mode set by classic fairy tales is deliberately created by Wilde for the sake of creation in form.

\section{CONCLUSION}

Wilde's A House of Pomegranates is complex in language, plot and theme, different from the tradition represented by Anderson and Grimm's Fairy Tales. The most distinguished three defining aesthetic features in A House of Pomegranates: the minute beauty and pain, the digression from the major plot and the unexpected death endings that meet no companion in traditional fairy tales, are all expressions of Wilde's esthetic ideas - art transcends morality and should be different from real life. Therefore, Wilde is conducting an unprecedented aesthetic experiment in the name of fairy tales.

\section{REFERENCES}

[1] Shillinglaw, Ann. (2006). Telling Beautiful Untrue Things: The Fairy Tales of Oscar Wilde, Ph D. dissertation, Loyola University.

\footnotetext{
${ }^{3}$ Wilde, Oscar. "The English Renaissance of Art." Essays and Letters. Kingbook International Foreign Digital. Library. 10. Nov. 2008. <http://202.119.108.52:8077/Soft_Show.asp?SoftID=5629>

${ }^{4}$ Ibid.

${ }^{5}$ Ibid.
} 
[2] Wilde, Oscar. (1968). The Happy Prince and Other Stories. London: London Dent.
[3] Wilde,
Oscar. (n.d.). Intentions1.
Kingbook
Ked10/10/2008). [4] Wilde, Oscar. $\quad$ (n.d.).
http://202.119.108.52:8077/Soft_Show.asp?SoftID=5744 (accessed10/10/2008).

International Digital Library.

[5] Wilde, Oscar. Essays and Lectures. (n.d.). Kingbook International Digital Library. 10 Nov. 2008. http://202.119.108.52:8077/Soft_Show.asp?SoftID=5629(accessed10/10/2008).

Jing Hou was born in Hunan, China in 1984. She received her MA in literature from Nanjing Normal University, China in 2009.

She is currently a lecturer in the School of Foreign Languages, Huaiyin Institute of Technology, Huai'an, China. Her research interests include British and American literature. 